\section{3-1993: How Far Have We Come in Women's Employment in Education?}

\section{MARIAN COURT}

\section{Abstract:}

In 1893, the year of women's enfranchisement, women teachers were petitioning for equal pay for work of equal value. In 1993, the year celebrating women's suffrage, how far have we come in struggles for equality? In this article, a brief overview of some historical concerns precedes an examination of the nature of present gendered hierarchies across and within the education services. Despite the equity legislation of the 1980s, there is a disturbing similarity between women's positions and concerns today and those of a hundred years ago. A discussion of issues related to an increasing casualising of work and demands for flexibility in management and labour relations is placed in the context of the restructuring of educational administration and the Employment Contracts Act.

\section{Introduction}

The contention is that equal work merits equal pay, therefore our first enquiry must be: what is the comparative value of the work... Men are no more ambitious to teach infants than they are to teach sewing. By one of the stupid conventions governing the world it is assumed that all women can fulfil both these duties, while no man may be supposed capable of either... [Yet] women are mulcted of sums varying - on the Southland scale - from 20 to 100 pounds per annum because they are women. Payment should be independent of sex. (Miss Bain, Southland Educational Institute, August 1893)
In 1993, women's average total weekly earnings are $\$ 491.17$; $\$ 176.49$ less than the average weekly earnings of men. (Department of Statistics, July 1993.)

Maori women belong to the group of women in the world who have been historically created as "Other" by white patriarchies and white feminism...Assimilation, where it has worked, has cut many Maori off from their own society and left them still on the fringes of Pakeha New Zealand... Colonisation has frequently made them invisible. (Linda Tuhiwai Smith, 1992, pp. 33 \& 35)

Istom

could seem churlish, at a time of celebration of women's suffrage, to raise issues of discrimination and worsening conditions for women teachers. Surely such women work in a comparatively privileged area of women's employment, where there have been considerable gains made over the last one hundred years? When we consider unemployment statistics for women, the situation of women in low paid segments of the labour market, increasing suicide rates for girls and unplanned pregnancy rates that are among the highest in the so-called developed world (as discussed by Anne-Marie O'Neill in the first of these two companion articles), the issues affecting teachers seem relatively insignificant. There are links between these phenomena, however, that need acknowledgment and attention.

\section{One Herstory of Women Teachers in Aotearoa/New Zealand}

Many stories could, indeed need to be told about the historical experiences of women in education in this country. By way of introduction to this article, what follows is an outline of some of the struggles groups of women teachers have engaged in over the last one hundred years.

Between 1877 and 1914, in an industrial relations environment that had devolved employment authority for primary schooling to twelve provincial education boards, local school committees 
had considerable input into staffing appointment and salary decisions. Arnold (1987, pp. 47-49) has documented the employment experiences of teachers during this time.

Teachers could not even be given guarantees of rough justice in the development of individual careers. They were virtually forced into the practice of "canvassing" committees for appointments, which too often reflected local whims and prejudices, rather than the relative professional competence of the applicants... Salaries varied markedly from board to board... The boards soon discovered the possibilities of an over-supply of well-educated young women ... [who] increasingly turned away from other work options such as domestic service and factory employment, and clamoured to get into teaching... Kept on at pupil teacher rates, they provided exceedingly cheap, high quality professional labour.

Unpaid (again mainly female) cadets were also used during the $1890 \mathrm{~s}$. Such young women were often teaching half-time in the hope of eventual employment as pupil teachers (ibid.) Young Maori women were also employed in these ways to teach within the Native schools. ${ }^{1}$

However, as is clear from Miss Bain's statement to her NZEI branch in Southland, there were women teachers who were fighting against inequalities in their conditions of service. In Arnold's view, "They were particularly active in 1893, the year of women's enfranchisement" (ibid, p. 50). As a result of their concerted and well organised efforts in lobbying, equal pay for women teachers was won in 1905, twelve years after Miss Bain's address. That this was not a popular move is also clear: it was not until 1919 that "the principle of equal pay (at least for single people) was being solidly endorsed by NZEI" (ibid, p. 42). Yee's (1985) analysis of the minutes of NZEI meetings indicates the extent of the resistance of male members of NZEI to the challenges of women teachers. In her discussion of extracts from the archives of the breakaway women's union, the New Zealand Women Teachers' Association, Roth (1985, p. 94) comments, "it is a little depressing to read 84 (now 92!) year-old discussions about male attitudes and women's pay and find them so drearily familiar - still. ${ }^{2}$ For example, in 1905, a clause in the Education Amendment Act stated that "at least one of the first three assistants in any school must be a woman" (cited in Roth, 1984, p. 97). Eighty years later, this was one of the aims in the secondary schools' Promotion of Women Review affirmative action strategy (initiated by PFTA in 1986). Roth's summary of archival material describes individual women's concerns that they should not be aggressive or work "in antagonism to men", but rather with them. However, the consequences of having no independent standing or representation in positions of power is illustrated by an episode in 1914. A clause inserted in the Education Amendment Act 1914, on the recommendation of the various women teachers' associations, to make provision for women inspectors, was "quietly struck out" when it came before the House for consideration (ibid, p. 99). It was not until 1926 that the first woman inspector of secondary schools was appointed.

The winning of equal pay in 1905 was a victory that was shortlived. Equal pay for women teachers occurred against a backdrop of the increasing normality of the cult of domesticity (James and Saville-Smith, 1989), a set of beliefs and practices which places on women the primary responsibility for child rearing responsibilities in the home. ${ }^{3}$ Further, in the 1920s the advent of the depression led to pressure for jobs for men as "breadwinners" for families. These combined circumstances contributed to the reinstatement of a separate scale for women teachers in 1925. The assumption was that a woman would (should) give up teaching on marriage, and that a single woman teacher would not need as high a salary as a man (who presumably would have a family. The responsibility that many single women carried for parents and other dependants was, of course, ignored here.) Equal pay was not won again until 1962.

From the 1930s to the late 1950s, married men received a marriage allowance on top of their already higher salaries. In 1932, a marriage bar was instigated whereby boards could refuse 
to employ a married woman, allowing such women to be pushed out of work and back into the home (and making more positions available for men). When the economy improved in 1938, legislation that was passed in 1931 to permit boards to sack married women, was repealed. On this repeal, one that Mr. Fraser said "is particularly desirable owing to the scarcity of teachers" (New Zealand Parliamentary Debates, Vol. 253, 1938, p. 417, cited in Yee, 1985, p. 79), married women were allowed back into the schools to be employed by boards as relieving teachers. Thus, the opinion was persisting that teaching work for women after marriage should be temporary. The underlying contradictions that married women should give priority to their "true vocation" of a good wife and mother, until they are required by the State to fill positions when teachers were scarce, remained masked in these official policy shifts.

The post-war "baby boom" led to another drive to recruit girls into, and married women back into, teaching. Despite the need for more teachers during this time, however, women's studentships were terminated if they married. "Marriage and a career were thus defined as antithetical by the state" (Middleton, 1988). In the seventies (at a time when the growth of school rolls had slowed), those returning to teaching after more than three years out of the service had to "re-train". These teachers were, of course, mainly women who had taken a break for family responsibilities. This is an example of another measure which put a brake on women's employment as teachers. As Yee points out, "women, especially married women, have served as an auxiliary labour force within the education system" (ibid) while no such expectation has been made of men. The story of women's movement in and out of the teaching workforce reveals how women's "flexibility" in the provision of labour has been required by, and worked to, the benefit of both the state and men. Throughout this century, men's jobs have had a protection not accorded to women, largely through men's handing over to women the primary responsibility for childcare.
During the late 1970s and the 1980s, as part of the second wave of the women's movement and within largely liberal feminist strategies, increased efforts by women to improve their position and working conditions did result in several gains being made for them. (For some detailed discussions see Steele, 1981; Watson, 1988, 1989). However, after the publishing of the State Sector Act, then the Picot Report and Tomorrow's Schools in 1988, many women expressed fears about the possible negative effects on women teachers of the devolution of educational administration within the context of free market economic policies and industrial relations. (In the light of the experiences of women within a devolved education system at the end of the last century, these fears are not unreasonable!) In response to the argument made in the Picot Report (1988, p. 24) that teachers were primarily concerned with their own conditions of service rather than for their students' learning needs, Travers (1989), for example, stated that women teachers were justifiably concerned about losing hard won concessions within male-defined conditions of service in education. She worried that under the Tomorrows' Schools proposals for restructuring educational administration, women would have to:

fight all over again to win rights such as maternity leave provisions, permanent part-time work, domestic leave for caring for family members), preference to get a job back after childcare leave. Women will be negotiating with predominantly male Boards of Trustees for such rights, and without the right to compulsory arbitration, since the State Sector Act removes this right (Section 75). History has shown that women have rarely won in negotiating situations with employers under so-called neutral conditions... and some women may not even get to the negotiating stage ... the employing Boards will prefer to employ men for the very reason that they will not press for the same conditions of service which women need (Travers, 1989, p. 36).

Some of these fears may have been allayed by the passing of the State Sector Amendment 1989. This required boards of trustees to 
put in place equal employment opportunities policies and programmes, to be "good employers" and to specifically address "the employment needs of women" (Section 77D). Women, along with Maori, people of ethnic and other minorities, and people with disabilities were to be the beneficiaries of programmes which would aim to remove discrimination in employment policies and practices. School charters would include specific equity goals for both equal educational opportunity and equal employment opportunity.

Since that time though, contradictions inherent in equal employment opportunities legislation have been identified (some of these are outlined later), and political commitment to equity concerns has been superseded by an emphasis on competition. Further, gender gaps in pay and status across the whole of the labour market have not been eliminated. In fact, in February 1993, "for the first time, labour force statistics showed a slight widening of the gender pay gap" (Hill, 1993, p. 101, citing Department of Statistics, Household Labour Force Survey, February, 1993). Although in education equal pay for women and men in the same positions exists in theory, as we will see, in reality, men as a group still earn more than women as a group across all sectors of this work force.

The 1993 celebration of women's suffrage is indeed ironic in these circumstances.

\section{Hierarchies of Status and Reward in Educational Workforces}

\section{The Position of Women in the Teaching Services}

When we consider the present position of women in relation to that of men working in the field of education, it seems that there have been few enduring gains made for women, despite some improvements following EEO legislation and affirmative action programmes in the 1980s. Surveys across the education sectors show that the gendered nature of a teaching hierarchy - from early childhood to tertiary workforces - is not breaking down. In fact, the distinctions are exacerbating. In the area of early childhood education (including kohanga reo and Pacific Island language nests), the area of least pay and ascribed low status, women make up the huge majority of workers (for example, women made up $99 \%$ of kindergarten teachers). The proportion of women in the primary, secondary and college of education teaching workforces has been steadily increasing over the last decade while in polytechnics and universities, the proportion of women has decreased during the last two years. In 1992 women were $78 \%$ of primary (up on $76 \%$ in 1990); $51 \%$ of secondary (50\% in 1990); $60 \%$ in colleges of education (49\% in 1990). Women were $40 \%$ in polytechnics (down from $41 \%$ in 1990) and $24 \%$ in universities (down from $28 \%$ in 1990) (Slyfield, 1992, 1993).

This increasing feminisation of the teaching workforce in areas where it is commonly perceived that knowledge is disseminated, while women are losing ground in the traditional areas of knowledge creation (the universities and increasingly polytechnics), is worrying. History has shown how women's contribution to knowledge has been overlooked and marginalised (Spender, 1982). If attempts to change persisting and destructive gendered inequalities in education (and indeed in society as a whole) are to be successful, women must be fully represented in all areas of knowledge creation, especially in universities - the traditional centres of control over knowledge discourses.

Of particular concern here is the silencing of tangata whenua women. As a consequence of colonising practices in Aotearoa/ New Zealand, their voices have been marginalised in dominant knowledge discourses. The distribution of Maori staff in 1990 as shown in the following table reveals their under-representation, on a population basis, as employees in most branches of education (Dunn et al., 1992, p. 23).

Pohatu (1988) has detailed the position of the only 48 Maori staff in the universities in 1987. Maori women then held only 4 senior lecturer positions, 8 lecturer positions and 2 assistant lecturer positions. Only one third of the Maori staff were female according to Slyfield (1992, p. 58). 
Table 1 Distribution of Maori Teaching Staff by Branch

\begin{tabular}{lcc}
\hline Branch & $\begin{array}{c}\text { Proportion of Maori Staff } \\
\text { Who Are Teachers }\end{array}$ & $\begin{array}{c}\text { Proportion of Staff } \\
\text { Who Are Maori }\end{array}$ \\
\hline Kindergarten & $87 \%$ & $4.5 \%$ \\
Primary & $54 \%$ & $7.0 \%$ \\
Area & $70 \%$ & $14.1 \%$ \\
Secondary & $70 \%$ & $5.5 \%$ \\
Polytechnic & $79 \%$ & $7.0 \%$ \\
College of Education & $71 \%$ & $12.5 \%$ \\
TOTAL & $\mathbf{6 4 \%}$ & $\mathbf{6 . 5 \%}$ \\
\hline
\end{tabular}

Source: Dunn et al., 1992, p. 23, Table 3.4

Women may have been enfranchised in 1893 in this country, but until very recently, little space or resources have been given to Maori women to enable them to develop and disseminate their knowledge within state educational institutions. The education developed and practised within Pakeha views of reality has clearly controlled and limited the participation and achievement of tangata whenua. In 1993 however, there were a growing number of Maori women working from "a diverse range of cultural considerations" to describe and analyse "differences which count" for them (Johnson and Pihama (1993, p. 18). This work has the potential to alter dramatically the monocultural nature of education and the work of teachers in this country. Women such as Johnson and Pihama are now placed to invert dominant discourses (of both white patriarchies and white feminism) and assert "our own definitions as opposed to those constructed outside of us, and re-present our realities through analyses in which we are at the centre" (ibid). (See also Smith, 1992; Irwin, 1992a; Pihama, 1993; Johnson, 1991).

It is clear then, that in the educational workforce there are differences between women and men and between different groups of women within education. These differences exist both across the education sectors and within each part of the service, operating on both vertical and horizontal planes. In particular, sexual divisions of labour result in women and men often being segregated into different kinds of work which are also valued differently. The resulting dynamics can not only affect the working conditions and career opportunities of many women, but also restrict women's opportunities to bring about change. An example from within universities may elucidate this dynamic. A recent survey of academic staff confirms earlier local and international findings that women in universities are more heavily involved in teaching than in research and publication (Vasil, 1993). Research and publication are significant knowledge creation and legitimation activities, and opportunities for involvement here can be jeopardised when women take on (or are given) heavy commitments in teaching. Research and publication have also been accorded more weight than teaching for academic staff promotion. So if women are not enabled to undertake more research and writing, not only are women's voices silenced in those areas, but their individual careers suffer. A further consequence is that women are likely to remain heavily under-represented in the universities' spheres of authority and decision-making and thus marginalised in the processes of policy formation and resource allocation. This, of course, impacts on wider groups of women both within and outside the university. ${ }^{4}$

\section{Gendered Careers: Women and Men in the Teaching/Administration Divide}

Value distinctions between the work of men and that of women in the educational services can be illustrated by looking at their relative placements. Men still dominate the "top" leadership positions while more women are placed in the "lower" levels of teaching/administration hierarchies. The following tables detail the position of women teachers relative to those of men in schools and universities. ${ }^{5}$

Table 3 details the position of women and men in positions of responsibility in secondary schools. We need to dig deeper to glean some of the ways gendered dichotomies and value 
Table 2 Primary Teaching Staff 1 March 1992

\begin{tabular}{lrrc}
\hline & Female & Male & $\%$ Female \\
\hline Designation & & & \\
Principal & 595 & 1,582 & $27 \%$ \\
Deputy Principal/AP, 2nd DP & 1,350 & 853 & $61 \%$ \\
Senior Teacher & 1,274 & 495 & $72 \%$ \\
Teacher & 14,022 & 1,978 & $88 \%$ \\
Other & 123 & 17 & $88 \%$ \\
Tenure & & & \\
Permanent and Provisional & 12,274 & 4,538 & $73 \%$ \\
Part-time & 3,767 & 175 & $96 \%$ \\
Relieving & 1,323 & 212 & $78 \%$ \\
TOTAL & 17,364 & 4,925 & $78 \%$ \\
Mean Age (as at 1 July 1992) & 40.7 & 42.9 & \\
Mean Salary (\$ permanent) & 32,828 & 39,008 & \\
\hline Source: Slyfield, 1993, p. 22 & & & \\
\hline
\end{tabular}

Source: Slyfield, 1993, p. 22

Table 3 Secondary School Teaching Staff 1 March 1992

\begin{tabular}{lrrr}
\hline & Female & Male & $\%$ Female \\
\hline Designation & & & \\
Principal & 59 & 257 & $19 \%$ \\
Deputy Principal & 126 & 253 & $33 \%$ \\
AP, 2nd Principal, SM & 155 & 113 & $58 \%$ \\
PR, HOD, ST & 2,090 & 3,189 & $40 \%$ \\
Teacher & 5,888 & 4,213 & $58 \%$ \\
Other & 23 & 4 & $85 \%$ \\
Tenure & & & \\
Permanent and Provisional & 5,579 & 6,912 & $45 \%$ \\
Part-time & 2,351 & 907 & $72 \%$ \\
Relieving & 411 & 210 & $66 \%$ \\
TOTAL & 8,341 & 8,029 & $51 \%$ \\
Mean Age (as at 1 July 1992) & 41.5 & 42.1 & \\
Mean Salary (\$ permanent) & 41,025 & 43,640 & \\
\hline
\end{tabular}

Source: Slyfield, 1993, p. 23
Table 4 University Teaching Staff 1 March 1992

\begin{tabular}{lrrr}
\hline & Female & Male & $\%$ Female \\
\hline Designation & & & \\
Vice-Chancellor/Deputy VC & 1 & 17 & $6 \%$ \\
Professor & 16 & 384 & $4 \%$ \\
Associate Professor/Reader & 36 & 379 & $9 \%$ \\
Senior Lecturer/Senior Tutor & 283 & 1,548 & $15 \%$ \\
Lecturer/Tutor & 588 & 755 & $44 \%$ \\
Assistant Lecturer & 220 & 239 & $48 \%$ \\
Other & 28 & 27 & $51 \%$ \\
Employment & & & \\
Full-time & 857 & 2,664 & $24 \%$ \\
Part-time & 315 & 685 & $31 \%$ \\
TOTAL & 1,172 & 3,349 & $26 \%$ \\
\hline Source: Slyfid, & & & \\
\hline
\end{tabular}

Source: Slyfield, 1993, p. 24

distinctions are working here against women teachers. The distinctions made between the so-called soft areas of the curriculum (e.g., humanities, arts, typing, home economics) where many women teach, and the hard areas (such as maths, physics, chemistry, engineering and now, technology) which are more often taught by men ${ }^{6}$, are reflected in the different PR status and monetary rewards for heading these different department areas. For example, heads of departments in home economics, typing or social studies have been more likely to be awarded a PR1 or PR2 status. PR3 and PR4 status has been more commonly given to heads of maths, science/physics, technical departments, or to those with responsibility in administration. Another distinction is the lower value given to the work of nurturing, as in pastoral care, (e.g., in dean's work in secondary schools) in comparison to the "technical" (and until recently male dominated) work of timetabling or the managing of aspects of the school's finances. Working in pastoral care positions such as Guidance has been considered to be a stuck career route from which it has been 
difficult to gain promotion, while the technical tasks have been considered as administration apprentice experience (Neville, 1988) ${ }^{7}$

Over the last five years, there has been little change in the proportion of women holding principals' positions, in both primary and secondary schools. In 1992, there were still only 3\% of women teachers who were principals in primary schools, while $32 \%$ of men in the primary service held principals' positions. Women remain more heavily represented in the smaller school positions, while most of the G4 and G5 large city primary schools have male principals. In 1992, only 15 of the 220 state and integrated co-educational secondary schools $(7 \%)$ had principals who were women (Slyfield, 1993).

Thus, although there has been a slight improvement in both applications and appointments of women at the lower levels of primary and secondary positions of responsibility, this improvement is not "trickling up" as many have maintained would happen. Between March 1989 and March 1991, only three women, in comparison with 20 men, were appointed to principals' positions in secondary schools (Slyfield et al., 1993, p. 28). Women's applications and appointments in the "top" principals' positions in the primary service are still not outnumbering those of men (despite the fact that women make up $76 \%$ of the primary service). It is worth noting here though, that an advertisement for one of these G5 positions, which stated "Applicants must demonstrate a commitment to equity in education and equal employment opportunities", had 15 women applicants and 9 men, while the median number of applicants for all G5 positions was one for women and 14 for men (Slyfield, 1993, p. 15). An influence on women's applications is their own (realistic) appraisal of their chances of positive consideration.

It is beyond the scope of this article to discuss fully the complexity of factors that have contributed to gendered splits between teaching and administration. Briefly though, it is significant that career advancement paths have been constructed in the past mainly by white men, based on their particular definitions of competence (Shakeshaft, 1987; Blackmore, 1989). Promotion is still gained in education by moving out of teaching (and management of class and individual learning), into management of the school as an organisation. In thinking about the nature of gendered hierarchies in schools, it is significant that the management of school classes and learning environments, where more women than men are situated, has rarely been described in administrative theory terms, nor given much attention in texts on school administration. Classroom management is more likely to be dealt with in "how to control your class" guides written mainly by (male) teacher educators for (mainly female) teachers.

The two areas of classroom and school management have been constructed as different in ways that link the skills and qualities seen as necessary for school organisation and administration to those commonly perceived (within Western culture at least), as masculine rather than feminine (Blackmore, 1993). Principals' positions have been seen as requiring among other things, an ability to be task oriented, rational in the organising of systems, good with figures, financial matters and plant management, as well as leadership qualities. Within hegemonic constructions of gender differences, such qualities and abilities have been generally excluded from dominant Western stereotypes of femininity, which have become associated rather with sexuality, emotionality, mothering, nurturing, being a supporter and follower (Connell, 1985,1987; Court, 1992, 1994). It is now being argued that these links work (often at fairly unconscious levels) to "define" women as less suitable for school administration and leadership positions than men, and more suited to teaching. ${ }^{8}$

Research studies are increasingly suggesting that "masculinist" models of career and definitions of "how to be a manager and leader" in schools, have "cooled out" many women from leadership (Grant, 1989; Al Khalifa, 1989; Blackmore, 1993; Court, 1994). Unless some far reaching changes are made in these 
areas, it has been argued that women will not choose to move into school leadership positions in any greater numbers. This may continue to benefit men's careers, but it means the present loss to the system of women's talents and qualities will continue.

\section{Equal Pay and Resources?}

The fact that more men advance up educational career ladders than women, results in some marked gender differences in average salaries for men and women. It is somewhat misleading then to assume that equal pay for men and women in education exists. Although within each sector, particular steps on salary scales are paid the same, regardless of whether the teacher is male or female, when the figures for mean and average annual salaries are compared, men, as a group, are paid more than women as a group. This reflects not only their representation in more of the management and senior positions within each sector, but also men's concentration in the higher status (working with older learners) areas in secondary and tertiary, rather than in primary and early childhood sectors.

For many women working in the early childhood sector, the issue of women earning less than men is allied to that of the low status of early childhood education in relation to the other education sectors. Dunn et al. (1993, p. 35) point out that "As kindergarten teaching has remained an overwhelmingly female domain, this highlights a serious issue of gender-related income inequity for this branch of the teaching service". The average salary of kindergarten teachers in 1990 was $\$ 28,371$; for primary teachers it was $\$ 34,697$; for secondary $\$ 42,671 ; \$ 45,138$ in polytechnics and $\$ 47,460$ in colleges of education. ${ }^{9}$ Despite the fact that most university teachers are required to gain graduate qualifications, the difference between the status and incomes of women in the top positions in early childhood and those of women in university professorships is stark. In 1993, a kindergarten senior teacher (working with Associations and many kindergartens, and carrying responsibilities in policy, staffing decisions, professional development and advice on curriculum development) could earn between $\$ 38,668$ and $\$ 41,858$. A university education professor (responsible for a department's policy, staffing decisions and professional development and development of research in education) could earn between $\$ 80,000$ and $\$ 99,000$. Miss Bain's question of 100 years ago is worth asking again here: "What is the comparative value of the work?"10

Within the early childhood sector, there are also differences in the resourcing and remuneration of those working in particular sections (such as those of kindergarten, childcare, playcentre, kohanga reo and Pacific Island language nest centres). The huge amount of voluntary assistance given in these centres is not reflected or taken into consideration in official reports on the labour force in the various centres and it is largely women who work in these ways. Differential funding has also placed a heavier burden on Maori women (and those of Pacific Island descent). The first kohanga reo opened in 1982; in 1991 there were 630 kohanga reo in operation, with the enrolment of Maori children having doubled from 4,132 in 1983 to 10,451 in 1991 (Davies and Nicholl, 1993, p. 27). The huge increase in centres, all of which "are based on the concept of whanau", was made possible by the unpaid work of many Maori women (Ministry of Women's Affairs, 1990, p. 20). Irwin states that Maori women were significant in leading the movement from their positions of being "the people at the cutting edge of social and cultural development" (Irwin, 1992b, p. 86)

For Maori working in kohanga reo, issues of cultural and language survival and development are inextricably bound up in political struggles (with Pakeha) over who makes the decisions.

In order for Te Kohanga Reo to be of any value and worthwhile for Maori interests and aspirations, Kohanga had to be controlled, defined and legitimated by Maori for Maori (Johnson, 1993, p. 3). 
Johnson argues that within present interpretations of the Treaty of Waitangi as a "partnership" document, the rights of Maori as tangata whenua have been overshadowed, with the "partnership between Maori and Pakeha being defined on Pakeha terms and proceeding only as far as Pakeha will allow it to" (ibid, p. 5). Struggling under severe financial hardships to support Te Kohanga Reo outside of the state system, Maori agreed to the movement's legitimation under the 1990 Education Amendment Act, "bringing it into line with the various other pre-school facilities" (ibid, p. 9). In Johnston's view, this has been at a cost for Maori, with integration into State system meaning that accountability structures have reversed. Rather than decision making and policy coming from the "grass roots" of the parents and whanau of each kohanga, policy is now handed down from the Ministry. Accountability is now also required to Social Welfare through the Income Support Services subsidies that some kohanga reo centres receive for their children. Here, Johnson points out that:

The criteria for the ISS subsidy will exclude many Maori parents from access to the finance which they will need to pay for their children's fees at Kohanga Reo... The emphasis of the changes is "retraining" and employment for parents encompassed within the notion that Te Kohanga Reo is a childhood care facility which will look after the children of parents who retrain and are "re-educated" (to enter the workforce) (ibid, p. 12).

"Parents", of course, largely means women, and often women in a solo parenting situation with insufficient funds to pay for tertiary fees or to support themselves through years of study. For such people, access to kohanga reo for their children is being cut back. Johnson further points out that in this Social Welfare policy, Te Kohanga Reo has been re-defined as a childcare facility - "a babysitting service" which parents can use for nine hours per week for subsidised childcare. In a personal communication to Johnson, the Minister for Social Welfare stated that this was "a reasonable time for children to gain educational benefits from early childhood education" (Shipley, 1993, p. 2, cited in Johnson, 1993, p. 13). Not so, states Johnson: nine hours per week is an inadequate time frame for Maori children to learn te reo Maori. Johnston argues that through these processes involving the control of funding, the State is subverting the purpose and aspirations of the kohanga reo movement: its differences from other areas of early childhood education are being "captured" and its "kaupapa becoming corrupted" (ibid, p. 14).

I have described this example in some detail to illustrate how the situations and experiences of Maori women working within education cannot be equated with the position and experiences of Pakeha women. The issues of gender are complicated and compounded by those of culture and tino rangitiratanga and struggles for resources. Within a Pakeha system, those whom the dominant group define as "different" have to constantly justify their very existence (Johnston and Pihama, 1993).

Within the historical development of Pakeha early childhood creches and education, women's struggles have been more closely tied to gendered politics. May argues that:

In general, the constraints of the workplace on both men and women have linked women's demands for a fairer share of economic resources and political power to the battle for provision and support of early childhood services. The history of early childhood services is embedded in the story of the changing roles of women in relation to their men, their children and their work (May 1993, p. 1).

The twin issues of care and education have been evident throughout much of early childhood history. Yet, despite political and social statements about the importance of the early years for learning, the status of women's work in the teaching of younger children remains low within state provided education.

Two further areas of significance in the educational "industry" can be drawn out from the figure below, those of part-time and non-teaching work. 


\section{All Employees Mean Income by Status and} Branch

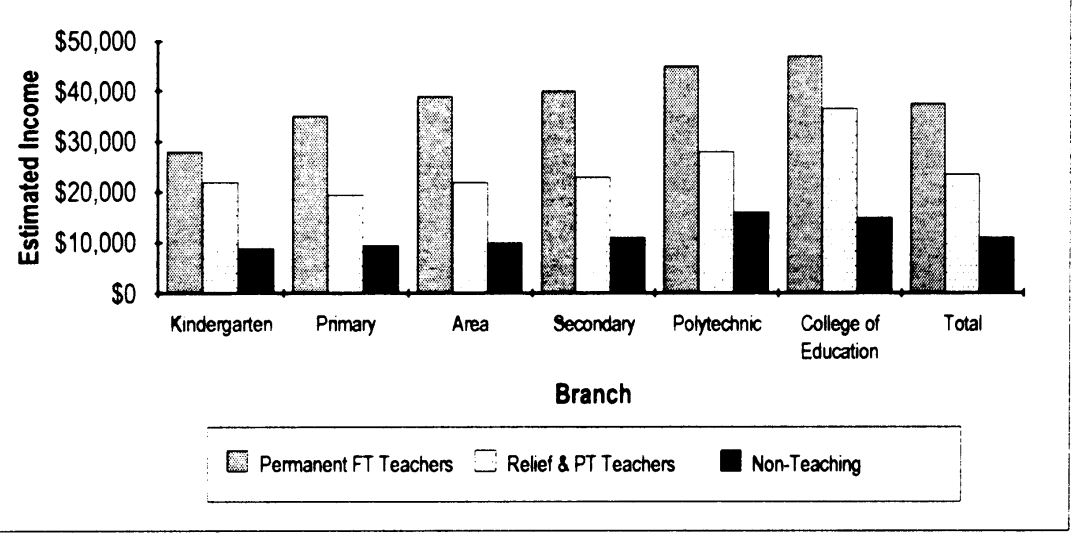

Figure 1 All Employees Mean Income by Status and Branch (Source: Dunn, Pole \& Rouse, 1992, p. 15, Figure 3.1)

\section{Part-Time Workers}

The dynamics of full and part-time work will be considered again in relation to my discussion of issues around the Employment Contracts Act. At this point, it is important to note that although in 1990 women made up $67 \%$ of all education sector workers, they were only $59 \%$ of full-time teaching staff. Women were $74 \%$ of all contract, relief and part-time teaching staff. These factors impact on both pay and the quality of employment conditions.

\section{Non-Teaching Staff}

We have until now been looking mainly at teaching positions in education. In 1990 there were 18,642 employees holding nonteaching positions on the Education Services Payroll. This means that nearly a third of all the positions in education are for services other than teaching (Dunn et al., 1993, p. 94).
Women make up $75 \%$ of this non-teaching staff, holding almost all clerical and office positions (92\% of such positions), $85 \%$ of teacher aide and assistant positions and over three quarters of health and other positions.

Income differences show up in several ways. In comparison with an estimated average salary (in 1990) of permanent fulltime teaching employees of $\$ 38,697$, the estimated average annual salary of full-time non-teaching employees was $\$ 10,338$. Within the permanent full-time non-teaching positions, women received less salary than men, with the exception of those in health positions. Overall, non-teaching women received $86 \%$ of the average income of non-teaching men (Dunn et al., 1993).

Security of tenure is a significant issue in these areas of employment as part-time status dominates non-teaching areas of work. More than two thirds (69\%) of staff here are in part-time positions.

The majority of non-teaching staff are of European descent, but Maori and Pacific Island people are only half as likely as others to hold clerical or office positions. A greater proportion of Maori women were in caretaking and cleaning positions than any other, while Pacific Island people were also more likely to hold cleaning or caretaking positions than other kinds of positions. Sixty-five percent of this group were caretakers or cleaners (Dunn et al., 1992, p. 101). In her discussion of the wider labour market, Du Plessis (1993, pp. 8-9) comments that:

In the cleaning industry there has been a steady decline in the availability of full-time jobs. Since Maori women and those of Pacific Island descent are over-represented in these jobs, they have been most affected by the lack of availability of access to full-time earnings.

The effects of historically developed institutional racism and sexism within our educational system is clear in these material realities for Maori and Pacific Island women. 


\section{Equity and Equal Employment Opportunities: Where to in the} 1990s?

\section{The Employment Equity Act ${ }^{11}$}

In 1990, on the passing of the Employment Equity Act, it could have seemed that the way was opening for a redressing of traditionally intransigent inequalities in gendered work relations. For example, under this legislation, the female dominated areas of the education workforce (early childhood and primary) could have sought parity with the secondary and tertiary sectors. However, it is clear that pay equity would have been at a cost to employers, and groups such as the Business Roundtable focused their efforts on defeating this legislation. Submissions made to the incoming National government in 1990 were:

framed in terms of costs to an economy in recession ... and part of a more general lobby for a de-regulated more competitive labour market and enterprise based bargaining. Employers' organisations not only opposed a state regulated increase in women's wages, but were seeking a shift to wage rates determined by competition, market forces and an employer's ability to pay (Hill, 1993, pp. 100-101).

The National government accepted these views and argued that the introduction of pay equity legislation was not a necessary intervention on the part of the State to achieve social justice in labour relations. Rather, it was an unacceptable form of "social engineering" that would interfere with individual rights and the working of a "free" market. The Employment Equity Act was repealed within three months of the new government taking office and work began on the introduction of the Employment Contracts Act (1991). ${ }^{12}$

\section{Equal Employment Opportunities and Women in Education}

It perhaps surprised some that National did not at this stage remove the EEO requirements in the State Sector Amendment 1989. Although there was much discussion about this for a time and the Minister of Education suggested making the equity goals of the school charters optional, these moves did not eventuate. It seems that National has not considered EEO any threat to their market agendas for education. Their approach to EEO is exemplified in the report of the keynote address at seminars during 1993 to present the findings of the "Work/Family Phonein" (organised by the Ministry of Women's Affairs to collect data on how people were juggling home and paid work responsibilities). The item notes that:

providing family/work programmes is a business investment... family friendly workplaces in the United States benefit from reduced absenteeism, improved recruitment and retention of staff higher morale and company loyalty and increased productivity (Ministry of Women's Affairs News Sheet, June 1993, p. 4).

That is, EEO strategies can be used to "enhance the business". The family/work seminars were sponsored by the Employers' Federation as well as the EEO Trust. It seems at first glance that this is a unlikely coupling. However, it should be understood that EEO can be easily accommodated by employers within particular labour market sectors. EEO does have potential for a radical redistribution of both gender and ethnic representation throughout the levels of the labour market, (and therefore is a goal which should not be jettisoned by feminists). Nevertheless, establishing EEO programmes that will ensure that members of discriminated against groups such as Maori, people of ethnic and other minorities, people with disabilities and women, are provided with access to employment opportunities and promotion, will not alter the salary accounts for employers. Thus, unlike pay equity, EEO does not challenge the economic bases and the financially discriminatory nature of gender segregated labour markets (for example, it will not challenge the different pay scales between early childhood and other sectors in education, or the higher rates paid for management positions in relation to those paid to teachers). Pay equity had the potential 
to alter these long entrenched differentials in salary packages and could have in the short term cost employers some considerable amounts of money. It is not surprising then that the pay equity legislation was quickly repealed under the National government.

Although EEO legislation was not removed, the way the law has been framed has been problematic for women from the start. Embedded in the State Sector Act there is a contradiction that reflects the liberal dualism of what Anne Else has analysed as oppositions between market man and family woman (1992, pp. 240-242). Employers are required to provide for "the employment needs of women". Unnamed here is women's delegated primary responsibility for childcare and the persisting assumption that it is women, not men, who "choose" to be responsible for childcare. Thus equal opportunities for women in educational institutions can be interpreted as meaning only that ways have to be found by employing agencies (boards of trustees) to provide "flexible" working arrangements so that women can fit the care of their children around their paid employment. O'Neill (1992b) has analysed how significant educational policy documents have both reflected and contributed to historical constructions of so-called "natural" dichotomies of masculinity and femininity. It is within an analysis of persisting contradictions between dominant liberal conceptions of equality and difference and commonsense understandings about what it means to "be" masculine or feminine, associated as these are with sexual divisions of labour, that the present positions and experiences of women in education need to be considered. Women's experiences as workers in education and the wider labour market must also be discussed within an understanding of the links between women's unpaid work in the home and the undervalued status of their labour in paid employment. This feeds into the ways that areas commonly seen as "women's work" (such as teaching in subjects like home economics or carrying out emotional, supportive work in guidance) are not given credit.
Although equal employment opportunities legislation has remained, it has little visibility in education. There is a requirement for institutions to report annually to the Minister of Education (through the Education Review Office) on their implementation of EEO policies and programmes; but there are no real sanctions against those who do nothing. The history of the EEO personnel in the Education Review Office illustrates a political lack of commitment to EEO. Thirteen EEO Review Officers were appointed when the Review Office was established in late 1989. In 1991 their titles were changed to Personnel Reviewers, signalling a removal of their specialist focus. In 1993 these positions were disestablished. These changes occurred within two staffing cutbacks in the Education Review Office in response to government fiscal requirements. However, the removal of the EEO Reviewers' specialist positions was also an obvious target within National's alliance with employers' groups such as the Business Roundtable. Their views that any intervention at the level of the state was contrary to the needs of the market and individual choice were in the ascendency and "National saw EEO as an issue best pursued voluntarily" (Hill, 1993, p. 103).

The removal of the EEO Reviewers needs to be also placed in the context of other cutbacks in areas where women had gained some ground for collectively identifying and voicing concerns about learning and work contexts for girls and women in education. In 1991, the Women's Advisory Committee on Women and Girls was disestablished. This was followed by the splitting up of the Girls' and Women's Section of the Ministry of Education which took effect in 1993. Late in 1993, the EEO Officer in the Ministry of Education left her job; at the time of writing, this position had not yet been advertised. These changes have occurred relatively quietly, with little public attention being drawn to them. Their significance has been overshadowed by justifiable public concern about issues of unemployment and health cutbacks. When peoples' basic needs for survival are under threat, parity issues become secondary. The competitive labour 
market and employers' profits are the areas to benefit in these circumstances, at the expense of equity and social justice.

In the early days of my experience as an EEO Reviewer in the newly established Education Review Office, reviewers were often asked by teachers and board members for advice and assistance in developing their policies and programmes. It seemed then that there were many people interested in developing change in this area. However, after the National government took office, it was not long before a strong statement was issued to us that the Minister of Education was the primary client of the Office. Reviewers were told that school reviews were an output of the Review Office; reviews that were being purchased by the state under the terms of the Chief Executive Officer's contract and the Office's Corporate Plan. Thus, reviewers' responsibilities were to serve "the Crown's interest in education (as investor and purchaser)" (Education Review Office, 1992, p. 4). It was expected that reviewers, many of whom were ex teachers and Department of Education inspectors, would shift their stance from that of working with teachers in a collegial model of co-operative review and assistance, to one of external "objective" reporters to their primary client, the Minister of Education. A "detailed examination of the output classes" (ibid, p. 5) of the Review Office was undertaken under the leadership of the newly appointed Chief Executive Officer, Dr. Judith Aitken. It is significant here that within National's free market agendas, the reviewing of schools has been re-written within the economic terminology of corporate businesses. The work of learning and teaching is now described in terms of inputs and outputs, and their review in terms of audit and compliance with legislative requirements.

The EEO legislative requirements of the State Sector Amendment Act remain "on the books" for schools, along with other legislation for aspects of social justice - for example, the Human Rights Commission Act, the Race Relations Act, the Treaty of Waitangi. Under these umbrellas, women and girls can press their claims. However, the messages in regard to social justice and gender equity are mixed - on the one hand, EEO is important enough to remain in legislation, on the other hand, acting on this legislation can remain voluntary. ${ }^{13}$

It is not therefore surprising to find ambivalence within school boards' implementing of equity requirements in their personnel policies. In the fourth quarter of 1992-3,

$41 \%$ of boards of trustees of schools had no policy to address the intent of the Treaty of Waitangi; $43 \%$ did not operate a personnel policy that met the principle of being a good employer; $73 \%$ had not implemented an equal employment opportunities programme; $32 \%$ had not developed effective procedures to eliminate sexual harassment (Education Review Office, 1993a, p. 3). [In] free kindergarten associations, 11 of the 14 associations which employ staff in kindergartens, had not complied... with the State Sector Act personnel management provisions. These provide for the fair and proper treatment of employees in all respects of their employment (Education Review Office, 1993b, p. 3).

Although in 1992, the Waikato Monitoring Today's Schools Project (Ramsay and Oliver, 1992) found that there seemed to have been a raising of awareness about equity issues, (Maori trustees in particular were committed to equity goals and determined to take advantage of the opportunities these have afforded for them), few of the equity questions were answered in their questionnaire survey. From the responses that are discussed in this Equity Report, it is clear that there were both positive and negative opinions about the value of the equity goals. The study found that there has been little evaluation of the implementation of the equity requirements of the school charters. Although the time frame is still perhaps too short to expect that schools will be undertaking self review of this kind, the ambivalent messages about Government's commitment to equity concerns must have influenced boards' prioritising of their efforts within what have been enormous work demands. The requirements of the Employment Contracts Act have added to these workloads. 
There are more pressing concerns here, though it seems to many analysts that as the end of this century approaches, we could be on the road back to the industrial ills of the $1890 \mathrm{~s}$.

\section{The Future in the Past? Women and the Employment Contracts} Act

The various ways the Employment Contracts Act (1991) has accelerated privatisation, contestability, site based negotiations, competition for "scarce resources" and a shift of negotiating power towards employers are now becoming clear (Harbridge, 1993). In their analysis of this legislation, Hammond and Harbridge (1993, p. 15) point out that one hundred years ago, "New Zealand was internationally heralded as a 'social laboratory'" for its determination to achieve equity through a raft of legislation, social and industrial policy developments.

The introduction of a legal regime based on the principles of collective labour law was an acknowledgment that the earlier regime based upon principles of "freedom of contract" was an inappropriate mechanism for the governance of the employment relationship. This had been well illustrated in the findings of the 1890 Sweating Commission. "Freedom of con tract", it had found, resulted in the exploitation of many workers, particularly women.

Researchers such as Hammond and Harbridge (1993) and Hill and Du Plessis (1993) locate a present worsening situation for many women workers in the reviving of contractarian rather than collective labour law. The Employment Contracts Act is grounded in a legal liberalism which assumes that the law provides a neutral mechanism (free from values and particular sets of interests) to support the exercise of individual "choice" and "freedom" in market bargaining and negotiation. However, the idea that this kind of free enterprise is the most appropriate for the efficacy of the market and the promoting of a general "social good" masks the inequalities it both supports and produces - inequalities of gender, ethnicity and class.
In particular, within Western gendered power relations, divisions in the labour market have been constructed in ways that channel many women into "low paid, dead end occupations" (see Hammond and Harbridge, 1993, pp. 16-17, for a discussion of these factors). In Aotearoa/New Zealand, Maori and Pacific Island women are disproportionately located in many of those "low paid dead end occupations" and these are areas where union protection has been largely lost. Hill (1993) has analysed how the introduction of the Employment Contracts Act has impacted on unions' power to negotiate national awards. Many of these have been fragmented into enterprise negotiations. Within the teaching service, the beginning of such fragmenting processes can be detected in the "picking off" of the kindergartens for the imposing of bulk funding of teachers' salaries. It is not surprising that it is this labour force (made up of $99 \%$ women) which has been the first to bear the brunt of bulk funding and attempts to drive down teachers' salaries and working conditions.

\section{Bulk Funding of Teachers' Salaries and Enterprise Bargaining}

Gordon (1992) has analysed how the theories of public choice and agency have cohered with economic and managerial approaches in the development of the political agendas underpinning the bulk funding of teachers' salaries. She traces here a shift from equity issues and arguments that bulk funding would be empowering for schools, to an emphasis on competition as the way to improve schools. It is clear though, that there has been strong opposition during the last two years to the imposing of bulk funding within an enterprise bargaining, competitive framework. In the Waikato Monitoring Today's Schools National Survey of Secondary Schools 2 (McGee, Keown and Oliver, 1993, pp. $20-24), 79 \%$ of principals, $91 \%$ of teachers and $75 \%$ of board of trustees were found to be against bulk funding. The concerns raised echo those identified by Wylie (1991) in primary and intermediate schools: concerns about workload implications, offloading onto boards what should be the government's 
responsibility, negative effects on board/teacher relationships and growing inequities between schools.

Within early childhood education, where bulk funding has been imposed, warnings are being issued about damage to working conditions for teachers and learning opportunities and environments for children. A survey of 149 kindergartens carried out in May and June of 1993 by the Council for Educational Research found that an increased pressure on centres to maintain rolls is being accompanied by "a considerable increase in staff and voluntary workloads, (with) emphasis on financial viability making it difficult to target financial resources to those in areas of social need". There was a widening of "resource gaps between kindergartens in low income areas and others" (Dominion, 1993, p. 8).

However, in the 1993-94 Corporate Plan of the Ministry of Education, equity issues are not mentioned in relation to bulk funding; rather it is stated that in kindergartens and schools, "a higher degree of enterprise bargaining and greater flexibility in teacher's pay and conditions" is desirable and that "the devolution of responsibility for industrial matters to school boards in the absence of a grant for teachers' salaries, could have results that are contrary to the Government's fiscal objectives" (Ministry of Education, 1993, pp. 26-27). The National Government's economic and managerialist agendas driving the directions of boards of trustees employer/employee relations are revealed in these statements. The intention is perhaps more clearly expressed in a State Services Commission (1993) document about the bulkfunding of teachers' salaries, which in their view could be a way to:

contain spending in the school sector.. where teacher salaries are centrally paid for on a "staffing first" basis, Boards would have few incentives to keep costs down... The devolution of the Teacher Relief budget to schools at the beginning of 1992 led a number of Boards to re-evaluate their policy in this area. In many cases, this has been successful in keeping costs down.
(The effects of changes on relief teaching are discussed in some more detail later. These moves have increased pressures on both boards and teachers.) Educators have strongly objected to this kind of "schools as businesses" approach, arguing that the processes of education benefit from collegial co-operative relationships, rather than the competition promoted by the Minister of Education as the way to equip young people for the "international marketplace" (cited in Gordon, 1992, p. 46).

An encouraging note in the struggles over bulk funding is that in 1992 school boards refused to accept responsibility for the negotiation of school cleaners and caretakers contracts, despite the fact that wages for these workers were bulk funded as part of each school's operation grant. The cleaners and caretakers also voted to take industrial action against having their awards split up. A multi-employer contract which was consequently negotiated was the result of the way in which the whole issue had "become linked to broader issues about which management functions were to be devolved to school boards and how much boards should be expected to act as autonomous business enterprises" (Hill and Du Plessis, 1993, p. 37). In the aftermath of the 1993 November general election, it may be that the government's mandate to impose its will on schools in relation to the issue of bulk funding could have taken a severe denting. It remains to be seen how far the new political climate of "consultation, co-operation and consensus" will extend into this industrial relations battlefield.

\section{Salaries Grant for Management and Bargaining}

A step on the way to full bulk funding in the primary and secondary sectors was taken with the introduction of the salaries grant for teachers in management positions, implemented from June 1993. This new arrangement may provide opportunities for more flexible management allocations and arrangements in schools, as noted in the Ministry's Corporate Plan (1993, p. 27), 
such as job sharing and different kinds of splitting up of tasks and ways of paying for particular responsibilities. However, it needs to be noted that flexible for the employer may mean one thing, but a quite different thing for teachers, especially those who are women.

In education we already have a gender divided service that splits the work of (mainly male) administrators away from that of (mainly female) teachers and support staff. Separating the funding and negotiation of individual contracts for senior management positions (such as principal, deputy principal and assistant principal) away from those for other teachers drives a deeper wedge between these two areas of work in schools. Already, many principals (who are mainly men) have won salary increases since 1990. The following maximum increases on a range of rates have been available for boards to give principals (subject to the principal's performance review): 1 July $1990+4.04 \%$; June $1991+.64 \%$; July $1992+6.86 \%$ (Middleton, 1993). During these three years however, the salaries of teachers (who are mainly women) have stood still. This is a real change in industrial relativities within education, one which reflects the growing emphasis on managerialism as the way to enhance "the marketplace".

The salaries' grant for management and negotiation of a separate collective contract for senior staff in schools has also opened up the way for further attempts to introduce individual contracts for all staff. As pointed out earlier, breaking the collective awards and powers of the unions has been a clear goal in National's deregulation of the labour market and attempts to bring increased competition into labour relations. As yet, the unions of the New Zealand Educational Institute (the primary teachers' union), the Post Primary Teachers' Association and the Association of Staff in Tertiary Education have held off attempts by the State Services Commission to end collective contracts for these groups. These have been hard won victories though, and not without cost to employment conditions of teachers. Some of the changes do not bode well for women in the light of documentation of men's advantages over women in terms of both negotiating power and positions of authority. It is likely that other distinctions between the salaries and conditions of men and women in the education service will occur if site based bargaining becomes the model for bulk funding of teachers' salaries.

There have been concerns expressed about the effects on women teachers of site based bargaining, where unequal distributions of power in employer/employee relationships could be especially harmful for women. Discussions with women involved in education union collective contract negotiations with the State Services Commission support Hammond and Harbridge's (1993, p. 17) argument that there is a:

patriarchal nature [to] the bargaining process. Bargaining has historically been the domain of males, the language is masculinist, the processes are adversarial and its concepts have been based on gendered notions of workers being fulltime male breadwinners. These processes have, for the most part, treated women as outsiders and are unfamiliar to many women workers. [Further] working women's choices are constrained by a gender segmented labour market..."Freedom of contract" has no advantages for women workers, and in fact, women are less well off under such a system.

An example of how contracts may be used to disadvantage some workers in a "free" market, is provided by PPTA, who report that some private schools: "are offering contracts which seem close to "harsh and oppressive". One sighted recently was unacceptable because it required a three month trial period with no necessary right to further employment; enabled a board to terminate a position without reason; restricted the leave requirements, the accumulation of sick leave and did not provide for the maternity grant" (PPTA, 1993a). 


\section{Eroding Conditions of Employment?}

\section{Appraisal and the Market}

As part of the last round of negotiations, the NZEI was required to concede performance appraisal linked to salary increases in the first three years of a principal's appointment. For primary teachers, annual service increments as of right are also now dependent on yearly appraisals by the principal who is required to attest competent performance (NZEI, 1992a, Section 5.11.1; 1992b, Section 5.4.2). Within the contract for senior positions, although these staff may have had an excellent appraisal, primary boards are empowered now to grant salary increments for these teachers according to "whether funding is available for the purpose" (NZEI, 1992a, Section 5.3.1). That is, boards can now argue that such increments may not be justified within their budget priorities. Market factors are also now built into recruitment and retention at this level. Boards can determine the initial salary of senior managers on "the ability of the employer to recruit the specific skill and/or experience required for the job" (Section 5.4.1). They are also able to pay more for some jobs/people according to the board's "ability to retain the specific skills/experience required for the job" (Section 5.5.1). Given the predominance of women in skill and subject areas that are not considered as an appropriate "training ground" for management, that men are the relatively "scarce resource" in primary teaching and that there is a prevalent perception that the particular skills required for management are more likely to be held by men than women, it is easy to see how these clauses could work heavily against women in the future.

Most teachers will probably agree that bringing in appraisal requirements may be one way to help identify areas of weakness which need development and also bring pressure to improve on those people who are not providing an adequate teaching service. However, gender issues related to performance appraisal need some more research before we can be sure that these processes will not further disadvantage women teachers. In the past, male perceptions of merit have been shown to be highly problematic for women (Burton, 1988). In the labour market of the 1990s, Hammond and Harbridge (1993, p. 28) report that, "Men are more likely to receive productivity based payments. This indicates a failure to resolve sexist notions of skill and productivity assessment". For example, feminist analyses of job evaluation schemes have shown how skills associated with human relationships are valued less highly than those to do with technical areas. How then will pastoral skills used by a woman dean in a secondary school, be valued by a principal who perceives the counselling of a distressed pregnant schoolgirl and her parents, not as work requiring skilled and sensitive interactions and judgments, but rather as part of a woman dean's "natural" sphere of influence, something that she is inherently suited to and good at as a consequence of her femininity? In thinking about who carries out performance appraisals, how these are done and what the results are likely to be, there are many issues which need more research. Issues around sexuality in public organisations need investigation, for example, (for some useful discussions see Hearn et al., 1989). Performance appraisal for teachers at its best will consider and take account of these kinds of issues; at its worst, it is a pessimistic scenario for women.

Within the tougher negotiating conditions that have emerged under the Employment Contracts Act, some other employment provisions for women working in primary schools have been changed, for the worse.

\section{Maternity Grant}

The previous maternity grant was paid to a woman on the birth of her child, but from 1 May 1993, the grant will not be paid until six months after her return to work (NZEI, 1992b, Section 6.3.7). The previous timing of this grant helped many families meet the costs of a new child when the money was needed. There will undoubtedly be savings to the government under the changed scheme if women do not immediately return to work. 
A related area which is being increasingly contested is the preferential provisions for re-entry after childcare. Under Section 2.3 of the primary teachers' collective contract, a woman can apply for the priority right of getting her job back after childcare leave. However, it is reported by union officers that schools are becoming highly resistant to this, making it difficult for some women to negotiate (Middleton, 1993).

\section{Relievers}

Changes have also been made in both the levels of payment for relieving teachers (there has been a cut in the possible maximum rate), and in the method of funding this work. As noted earlier, the Teacher Relief Fund was included in the bulk allocation to schools during the past year, with the result that many schools have cut back on their calling in of relievers for fear that their funds would not stretch to cover the whole year. Relievers' opportunities for work have thus diminished. There are particular disadvantages for women here, as many relievers are women who are in the "break for childcare" stages of their careers. This is a time when many women teachers fill a reserve army of labour role; they are called upon in times of need to fill gaps in the workforce and are dispensed with when the need is past. As pointed out at the beginning of this article, there have been historical patterns of exploitation in the use of women in these ways.

In the cuts on calling in relievers though, permanent teaching staff (the majority of whom are also women) have also suffered, as they have been required to cover colleagues' classes. These demands contribute to the rising work loads and stress levels of teachers which are now being documented in the wake of Tomorrow's Schools (see e.g., Sullivan, 1993; Bridges, 1992). It is evident from these studies, and from anecdotal material, that not only is there an intensification of teachers' work occurring in our country, but also this work is increasingly encroaching on family life. Overseas analyses of the effects of such intensification need to be heeded here. Apple (1986) has shown how intensification impacts more severely on areas of women's labour.

\section{Part-timers and Casualising of the Workforce}

Exploitation can also arise in the way part-time workers are treated. In schools, part-time positions have increased between 1990 and 1992 by $49 \%$ for primary, 27\% for area schools and $22 \%$ for secondary. These increases are reflecting a wider casualising of the workforce in the wake of the Employment Contracts Act.

Permanent part-time positions and flexible work arrangements have long been argued for by women unionists as a way to facilitate women's negotiation of their work in both their homes and in paid workforce. In educational institutions, permanent tenure for part-timers has been difficult to establish, however, and as I have already pointed out, "flexibility" is a two-edged sword for women: flexible for whom? is the question which must be asked. From the discussion of women's historical experiences in educational workforces as a reserve army of labour for government and management, it is clear that women are at risk in labour market environments that heavily favour employers.

Sayers (1992, p. 1) points out that in discussions of part-time work the term "flexibility" is used:

as if it was universally agreed that it is both desirable and morally neutral ... for most women it means that their labour, both in the paid world of work and in the unpaid sphere of the home and the voluntary sector, is becoming increasingly marginalised and vulnerable.

Sayers discounts the possible empowering effects of flexibility for women who have traditionally negotiated two work spheres of home and paid work. She points instead to the likelihood of particular exploitation of women in secondary or peripheral labour market positions, such as, in education, those in nonteaching positions - teacher aide, clerical, cleaning and caretaking 
positions. As a consequence of perceptions that these are areas of low levels of skill, where "quality is not taken seriously and the workforce is divorced from the product-a pair of hands divorced from the brain" (Rainbird, 1990, p. 96), these areas of work are at risk of becoming distilled in the present climate. Workers in these areas are in Sayers' view unlikely to benefit from skill enrichment that many men have experienced during the restructuring of the 1980s (Sayers, 1992, p. 9).

Although women part-time teachers can be classified as members of a primary education labour market, and can be seen as protected to some degree by the fact that most have specialist skills and/or qualifications (teaching certificates and other qualifications such as reading recovery or Te Reo and tikanga Maori accreditation) which schools may need, within the present pressure on jobs under a falling rolls situation, those in part-time positions are particularly vulnerable to exploitation and insecurity of tenure. In an article entitled "Flexibility or exploitation?", the PPTA (1993b) reports on a recent survey of 410 part-time teachers (52 men and 351 women), noting that:

part-timers are overwhelmingly a female group who choose part-time work for the flexibility it offers those with family responsibilities, but who do not choose the often unacceptable conditions that accompany such work.

The survey found that the main concerns of these part-timers were absence of tenure, inadequate communication and timetabling difficulties. As a consequence of the intensification of teachers' work, many part-timers are picking up more administrative and extra-curricular work. Many part-timers often work longer hours than those for which they are paid. One woman commented that as a consequence of timetabling difficulties her time at school was scattered and she ended up working 25 hours, while being paid for 12 . Although this is perhaps an extreme case, from my knowledge of schools, this kind of situation is not an unusual occurrence.
Part-time teachers are less likely to be on the formal and informal networks that could assist their understanding of issues that may affect them and provide for them opportunities for voicing their concerns and needs. Consequently they can miss out on professional development opportunities. Presently this a matter of considerable concern, as such women are unlikely to experience the up-skilling being offered within the professional development programmes to equip teachers' implementation of new curriculums.

Security of tenure is perhaps the most serious issue for nonpermanent part-timers. As one teacher said: "It is a constant worry where my next meal is coming from". Another wrote "Every time the Education Act changes, or the government, or the weather, I can lose my job" (PPTA, 1993b). Although no figures are available, anecdotal evidence is suggesting that part-timers are the teachers in secondary schools who have being losing their jobs in the recent round of terminations that have resulted from falling school rolls. The situations and experiences of part-timers urgently need further researching to identify what factors are operating in this sphere of employment in all the education sectors, under the Employment Contracts Act.

\section{Conclusion}

This article has focused on particular areas of concern for women working in education, providing a partial view of some of the structural divisions and inequalities of gender, ethnicity and class that exist in this workforce. It is clear that complex hierarchies of status and reward persist within and across the educational sectors.

Feminist scholarship has identified how, under-pinning the gender divisions I have been describing, there is a derogation of women and women's minds, abilities, work and achievements. Feminist philosophersin particular have traced this derogation to the androcentric and often misogynist nature of western Enlightenment epistemology, a world view that has been 
supported to the advantage of mainly white men (Hekman, 1990, p. 188). In liberal political discourses, as discussed by $\mathrm{O}^{\prime} \mathrm{Neill}$ (1993 and 1994 this volume) individuals are conceptualised in abstract, neutral terms. This conceptualising stresses individual autonomy and rationality, and presumes that everyone has equal personal capacities and resources. What is not taken into account is how each person negotiates, in different ways, in different times and places, a range of subjectivities and positions within "the market(s)". Gender, race and class are significant here. In particular, for women it is significant that qualities defined as masculine have been linked to the characteristics of autonomous rational individuals. This linking has been used to support arguments justifying men's dominance in the political and economic activities of public organisations. Women have been variously defined as "other" (to men), and relegated to "other" duties as a consequence of their "different" sexuality. Of course, ethnicity and class also impact on the ways these processes occur and where particular women are "placed" in society. Generally though, women's place in a man's world has been moved to "the periphery rather than at the center" (Hekman, 1990, p. 154). Within this framework, hegemonic links have been developed between a conception of "natural" femininity as caring and nurturing (as a supposed consequence of female biological factors) and the work associated with childrearing and domesticity. In Aotearoa/New Zealand, dominant discursive practices of mothering have been developed within a Pakeha view of the cult of domesticity, a set of values, beliefs and practices imported with colonial settlement from Britain which place women as primarily wives and mothers (James and Saville Smith, 1989).

The educational workforce provides an example of how the domestic sphere, the school and the labour market interact in the production and reproduction of these kinds of gender relations. While men and fathering are linked with "masculine" authority and leadership, for women, mothering and teaching (especially the teaching of smaller, younger children) are taken for granted as "naturally" linked. This association is expressed in statements such as "teaching is a good job for a girl"; it will use her "natural" abilities and provide a "short adventure between school and marriage" (Middleton, 1988). The expectation continues that, after she has had a family, (and within the discourse of compulsory heterosexuality (Rich, 1977) all women are assumed to want this destiny) a woman will easily be able to go back to work because "she'll be able to be at home for her kids during the school holidays". These views, that the work of mothering (in both the home and the school labour market) is a choice that should be made by all women and only by women, must be challenged.

Analysis of women's varying participation in paid work must also move beyond examinations that work only at the level of ideological stereotypes. Motherhood needs to be understood as an institution:

a set of social relations within which caring labour is exploited; it can be conceptualised as a structuring process of gender, which is not confined to the domestic sphere, but is also in operation in the labour market. As such it can be considered to be potentially not only constitutive of occupations but also, in part, produced by the labour market (Adkins and Lury, 1993, p. 178).

The historical, and continuing exploitation of women's work in education as carers within the two sites of home and school becomes clearer within this conceptualising, elucidating how the discursive practices of motherhood have not only increasingly constituted and defined the occupation of teaching, but have also contributed to the production of wider gendered inequalities. They underpin, for example, women's concentration in a narrow range of mainly low paid jobs such as cleaning, clothes sewing, teaching, nursing, clerical and service work. Assigned to a further racial category, Maori and Pacific Island women have been defined as inferior and "deviant" in relation to the "norm" of Pakeha women, ideologically justifying their relegation to the lowest status areas of work and increasingly, unemployment (see O’Neill, 1994, this volume). 
In the light of these understandings, and the discussions of women's experiences in education, we need to consider carefully where our efforts can be best focused to bring about change for women in Aotearoa/New Zealand, change that can endure.

\section{Notes}

1. As well as working to assimilate Maori into a European way of life, these schools aimed also to train Maori girls into European forms of domesticity (Fry, 1985). Coney (1993, pp. 194-195) provides, however, evidence of Maori women's resistance to these colonising practices, and points out the irony that the Native School System gave some Maori girls a vocational opportunity not tied to domestic life.

2. The women's union first formed a branch in Christchurch in 1901. Other branches were established and in 1914, in response to the threat of a cutting back of pay scales, these branches formed the national federation, the New Zealand Women Teachers' Association. This association continued until 1962, though it was not considered by the women in Else's study to be particularly politically active in its last years (Else, 1986, p. 112).

3. O'Neill (1992a, 1992b, 1993) has analysed the effects of the cult of domesticity, the eugenics movement and the campaigns of medics such as Drs King and Bachelor, on the historical development of education and employment opportunities of girls and women.

4. An optimistic note here is an indication that universities are currently considering ways of ensuring that teaching is given more weight in the approval of promotion applications. This could have a long-term impact on the number of women in more authoritative positions. However, a cautionary note is that if women choose to remain more heavily represented in teaching rather than in research and publication, then opportunities to deconstruct and re-vision dominant male discourses will be missed.

5. Figures for early childhood education can be found in Slyfield, 1992. For figures on area schools, colleges of education and polytechnics see Slyfield, 1992, 1993; Dunn, Pole and Rouse, 1992.
6. See O'Neill (1992b) for a more detailed discussion of the historical development of these curriculum distinctions.

7. For discussions of these kinds of segregations in other work places and labour markets see Cockburn, 1985; Game and Pringle, 1983.

8. However "suitable" for teaching women may have been considered, their contributions have not been valued as equal to those of the men who work in this field. Statistics on women's promotion demonstrate this fact.

9. Dunn et al. (1993, p. 84) note here that the higher average salary for teachers' college staff reflects a higher ratio of senior positions than in polytechnics, and the fact that college lecturers earn a higher rate than their tutor counterparts in polytechnics. Although I could not locate the average salary figures for universities, salary scales for lecturers in my own university are: graduate assistant - fixed rate of $\$ 17,355$; starting rate for assistant lecturer - $\$ 31,200$; lecturer - $\$ 37,440$; senior lecturer $-\$ 52,000$; associate professor $-\$ 69,680)$.

10. The comparative positions of women and men in the universities need to be remembered here, as the majority of the top positions in tertiary education are held by men. In 1992, women made up only $24 \%$ of university teaching staff, being heavily represented at the assistant lecturer and lecturer levels, while only $4 \%$ of professors' positions were held by women (Slyfield, 1993, p. 24).

11. Linda Hill provides a helpful set of definitions here. "Equal pay: Women and men get the same pay for the same job. Pay equity: Women and men get the same pay for different jobs with comparable skill, effort, responsibility and conditions of work. Comparable worth assessment: Job evaluations and comparisons based on skill, effort, responsibility, conditions of work (issues of gender bias in methodology). Equal employment opportunity: Aims to improve the distribution of women, Maori and Pacific Islanders and disabled workers in better-paying jobs and positions of responsibility. Anti-discriminatory, encouraging training. Not affirmative action, targets or quotas. Employment equity: All of the above. (1993, p. 96). 
12. For recent discussions of employment equity, see Wilson, 1993; Hill, 1993.

13. As evidenced in the Minister's 1990 questioning of the compulsory status of the equity goals.

\section{References}

Adkins, L. and Lury, C. "Gender and the labour market: old theory for new?" in Hinds, H., Phoenix, A. and Stacey, J. (eds) Working Out: New Directions for Women's Studies, London: Falmer Press, 1993.

Al Khalifa, E. "Management by halves: women teachers and school management" in De Lyon, H. and Widdowson Migniuolo, F. Women Teachers: Issues and Experiences, Milton Keynes: Oxford University Press, 1989.

Apple, M. Teachers and Texts, New York: Routledge and Kegan Paul, 1986.

Arnold, R. "Women in the New Zealand teaching profession, 1877 1920" in Openshaw, R. and McKenzie, D. (eds) Reinterpreting the Educational Past, Wellington: NZCER, 1987.

Bain, Miss "The remuneration of teachers" in The New Zealand School Master, August 1893.

Blackmore, J. "'In the shadow of men': The historical construction of administration as a "masculinist' enterprise" in Blackmore, J. and Kenway, J., Gender Matters in Educational Administration and Policy, London: The Falmer Press, 1993.

Bridges, S. Working in Tomorrow's Schools: Effects on Primary Teachers A Christchurch Study, Research Report No. 92-3, Education Department, Canterbury University, December 1992.

Burton, C. Redefining Merit, Monograph No. 2, Australian Affirmative Action Agency, 1988.

Cockburn, C. Machinery of Dominance: Women, Men and Technical Knowhow, London: Pluto Press, 1985.

Coney, S. (ed) Standing in the Sunshine: A History of New Zealand Women Since They Won the Vote, Auckland: Viking, 1993.

Connell, R. Teacher's Work, London: Allen and Unwin, 1985.

Connell, R. Gender and Power: Society, the Person and Sexual Politics, Cambridge: Polity Press, 1987.
Court, M. "Women in educational administration: constraints on their promotion", in Women's Studies Association Conference Papers, Christchurch, 1989.

Court, M. "'Leading from behind": women in educational administration" in Middleton, S. and Jones, A. Women in Education in Aotearoa 2, Wellington: Bridget Williams Books, 1992.

Court, M. "Removing macho management: lessons from the field of education" in Gender, Work and Organisation, 1:1, 1994.

Davies, L. and Nicholl, K., Te Maori i Roto i nga Mahi Whakaakorangal Maori in Education, Wellington: Ministry of Education, 1993.

Department of Statistics/Te Teri Aotau o Aotearoa, Key Statistics, July 1993, Wellington: Department of Statistics, 1993.

Dunn, A., Pole, N. and Rouse, J., The Education Sector Workforce, Wellington: Ministry of Education, 1992.

Du Plessis, R. “Unfinished business: economic independence for women", University of Auckland Winter Lecture, 27 July 1993.

Education Review Office, Report of the Education Review Office for the year ended 30 June 1992, Wellington, 1992.

Education Review Office, Fourth Quarter 1992-93 Overview Analysis Assurance Audits and Effectiveness Reviews of Schools, Wellington, August 1993a.

Education Review Office, Fourth Quarter 1992-93 Overview Analysis Assurance Audits and Effectiveness Reviews of Early Childhood Centres, Wellington, August 1993b.

Else, A. (ed) Listen to the Teacher: An Oral History of Women who Taught in New Zealand 1925-1945, Wellington: Society for Research on Women, 1986.

Else, A. "To market and home again: gender and the New Right" in Du Plessis, R., Bunkle, P., Irwin, K., Laurie, A. and Middleton, S. (eds) Feminist Voices: Women's Studies Texts for Aotearoa/New Zealand, Auckland: Oxford University Press, 1992.

Fry, R. It's Different for Daughters, Wellington: NZCER, 1985.

Game, R. and Pringle, R., Gender at Work, Sydney: George Allen and Unwin, 1983. 
Gordon, L. "The bulk funding of teachers' salaries" in Manson, H. (ed.) New Zealand Annual Review of Education, 1:1991, Wellington: Faculty of Education, Victoria University of Wellington, 1992.

Grant, R. "Women teachers' career pathways: towards an alternative model of career" in Acker, S. (ed.) Teachers, Gender and Careers, New York: Falmer Press, 1989.

Hammond, S. and Harbridge, R. "The impact of the Employment Contracts Act on women at work" in New Zealand Journal of Industrial Relations, 18(1), 1993, pp. 15-30.

Harbridge R." Collective employment contracts: a content analysis", in R. Hardridge (ed) Employment Contracts: New Zealand Experiences, Wellington: Victoria University Press, 1993.

Hearn, J. et al. (eds) The Sexuality of Organisations, London: Sage Publications, 1989.

Hekman, S. Gender and Knowledge: Elements of Post-Modern Feminism, Cambridge: Polity Press, 1990.

Hill, L. "100 years of the vote: 80 per cent of the pay: The politics of pay equity", in Women's Studies Journal, 9:2, 1993, pp. 87-113.

Hill, L. and Du Plessis, R., "Tracing the similarities, identifying the differences: Women and the Employment Contracts Act", in New Zealand Journal of Industrial Relations, 18(1), 1993, pp. 31-43.

Irwin, K. "Towards theories of Maori feminism", in Du Plessis, R., Bunkle, P., Irwin, K., Laurie, A. and Middleton, S. (eds.) Feminist Voices: Women's Studies Texts for Aotearoa/New Zealand, Auckland: Oxford University Press, 1992a.

Irwin, K. "Maori education in 1992: a review and discussion", in Manson, H., (ed) New Zealand Annual Review of Education 2:1992, Wellington: Faculty of Education, Victoria University of Wellington, 1993.

James, B. \& Saville Smith, K. Gender, Culture and Society, Auckland: Oxford University Press, 1989.

Johnston, P. A Fair Measure of Influence? Maori Members on School Boards of Trustees, Unpublished MA Thesis, Education Department, University of Auckland, 1991.
Johnston, P. "Examining a State relationship: Legitimation and Te Kohanga Reo - the return of the prodigal child?" Paper presented at NZARE Conference, Hamilton, 1993.

Johnston, P. and Pihama, L. "What counts as difference and what differences count: gender, race and the politics of difference", Paper presented at NZARE Conference, Hamilton, 1993.

May, H. "When Women's Rights Have Come to Stay, Oh Who Will Rock the Cradle?" Early Childhood Care and Education in Women's Suffrage 1989-1993, Hamilton: Department of Early Childhood Education, Waikato University, 1993.

McGee, C., Keown, P. and Oliver, D. Monitoring Today's Schools: National Survey of Secondary Schools 2, Hamilton: University of Waikato, 1993.

Middleton, L. Personal communication, NZEI, 9 November, 1993. Middleton, S. "A short adventure between school and marriage? Contradictions in the education of the New Zealand 'post-war' woman" in Middleton, S. (ed) Women and Education in Aotearoa, Wellington: Allen and Unwin/Port Nicholson Press, 1988.

Ministry of Education, Corporate Plan, 1993-94, Wellington: Ministry of Education, 1993.

Ministry of Women's Affairs, "Mana Wahine" in Women in New Zealand, Wellington: Department of Statistics and Ministry of Women's Affairs, 1990.

Ministry of Women's Affairs, News Sheet June 1993, Wellington: Ministry of Women's Affairs, 1993.

Neville, M. Promoting Women: Successful Women in Educational Management, Auckland: Longman Paul, 1988.

NZEI, Primary Principals', Deputy and Assistant Principals' Collective Employment Contract 1992/94, Wellington: NZEI, 1992a.

NZEI, Primary Teachers' Collective Employment Contract 1992/94, Wellington: NZEI, 1992b.

O'Neill, A. M. “The equal opportunity myth: women in New Zealand educational institutions" in Olssen, S. (ed.) The Gender Factor: Women in New Zealand Organisations, Palmerston North: Dunmore Press, 1992a. 
O'Neill, A. M. "The gendered curriculum: homemakers and breadwinners", in McCulloch, C. (ed) The School Curriculum in New Zealand, Palmerston North: Dunmore Press, 1992b.

O'Neill, A. M. "Educational policy initiatives for girls and women: are we included in the decent society?" in Manson, H. (ed) New Zealand Annual Review of Education 2:1992, Wellington: Faculty of Education, Victoria University of Wellington, 1993.

Picot, B. et al., Taskforce to Review Educational Administration, Administering for Excellence (Picot Report), Wellington: Government Printer, 1988.

Pihama, L. Tungia Te Ururua, kia Tupu Whararitorito te Tupu o te Harakeke: A Critical Analysis of Parents as First Teachers, Unpublished MA Thesis, Education Department, University of Auckland, 1993.

Pohatu, C. "The Watts' Report: implications for Maori in southern universities: an opinion", in New Zealand Journal of Educational Studies, Vol. 23, No. 1, 1988, pp. 75-85. PPTA. Branch Bulletin, Vol. 4, No. 39, 17 November, 1993a.

PPTA. "Flexibility or exploitation? Women as part-time teachers" in 1993 Suffrage Centennial Supplement, Wellington: PPTA, 1993b.

Rainbird, H. Training Matters: Union Perspectives on Industrial Restructuring and Training, Oxford: Basil Blackwell, 1990.

Ramsay, P. and Oliver, D. Monitoring Today's Schools: Report No.10, Equity, Hamilton: University of Waikato, 1992.

Rich, A. Of Women Born: Motherhood as Experience and Institution, London: Virago, 1977.

Roth, M. "Archives: Association of women teachers in 1901", in New Zealand Women's Studies Journal, April 1985, pp. 93-108.

Sayers, J. Women, the Employment Contracts Act and Labour Flexibility, Working Paper Series 2, Department of Human Resource Management, Massey University, 1992.

Shakeshaft, C. Women in Educational Administration, London: Sage Publications, 1987.

Slyfield, H. An Overview of Equal Employment Opportunities in the Teaching Services, Wellington: Ministry of Education, 1992.

Slyfield, H. The Position of Women in the Education Services, Wellington: Ministry of Education, 1993.
Slyfield, H. et al., Teacher Mobility Study 1989-1991, Wellington: Ministry of Education, 1993.

Smith, L. "Maori women: discourses, projects and Mana Wahine" in S. Middleton and A. Jones (eds), Women and Education in Aotearoa 2, Wellington: Bridget Williams Books, 1992.

Spender, D. Women of ldeas - and What Men Have Done to Them, London: Routledge \& Kegan Paul, 1982.

State Services Commission, "Internal document, July 1993", in PPTA, Branch Election Kit: 1993, Wellington: PPTA, 1993.

Steele, J. An Evaluation of In-Service Training: Women in Management 1978-1980, Unpublished MEd Dissertation, Education Department, Massey University, 1981.

Sullivan, K. "The myth of partnership: educational reform and the disempowering of teachers" in Manson, H. (ed) New Zealand Annual Review of Education 2:1992, Wellington: Faculty of Education, Victoria University of Wellington, 1993.

The Dominion, "Preschool quality threat", Wellington: 28 August, 1993, p. 8.

Travers, A. "The State Sector Act and Tomorrow's Schools: implications for women" in Delta 41, 1989, pp. 33-39.

Vasil, L. "Gender differences in the academic career in New Zealand universities", in New Zealand Journal of Educational Studies, 28:2, 1993, pp. 143-153.

Watson, H. "The impact of the second wave of the women's movement on policies and practices in schools" in Middleton, S. (ed) Women and Education in Aotearoa, Wellington: Allen and Unwin/Port Nicholson Press, 1988.

Watson, H. "Getting women to the top: the Promotion of Women Review", in PPTA Journal, Term 2, 1989.

Wilson, M. "The making and repeal of the Employment Equity Act: what next?" in Women's Studies Journal, Vol. 9, No. 2, 1993, pp. 68-86.

Wylie, C. The Impact of Tomorrow's Schools in Primary Schools and Intermediates 1990 Survey Report, Wellington: NZCER, 1991.

Yee, B. Women in the Primary Service: A Study of Their Access to Power and Decision Making, unpublished MEd Thesis, Canterbury University, 1985. 


\section{The author}

Marian Court has been a Lecturer in the Education Department at Massey University for two years where her research and teaching interests are in the fields of feminist theory, education, leadership and work. She has taught in primary and secondary schools and worked briefly as an equal employment opportunities reviewer in the Education Review Office. 